\title{
Correction to: Can methods of artificial intelligence aid in optimizing patient selection in patients undergoing intrauterine inseminations?
}

\author{
Nejc Kozar ${ }^{1,2}$ (D) Vilma Kovač ${ }^{1,2} \cdot$ Milan Reljič $^{1,2}$ \\ Published online: 28 June 2021 \\ (C) Springer Science+Business Media, LLC, part of Springer Nature 2021
}

\section{Correction to: Journal of Assisted Reproduction and Genetics https://doi.org/10.1007/s10815-021-02224-y}

The article Can methods of artificial intelligence aid in optimizing patient selection in patients undergoing intrauterine inseminations?, written by Nejc Kozar, Vilma Kovač and Milan Reljič, was originally published electronically on the publisher's internet portal on May 24, 2021 without open access. With the author(s)' decision to opt for Open Choice the copyright of the article changed on June 17, 2021 to (C) The Author(s) 2021 and the article is forthwith distributed under a Creative Commons Attribution.

The original article has been corrected.
Open Access This article is licensed under a Creative Commons Attribution 4.0 International License, which permits use, sharing, adaptation, distribution and reproduction in any medium or format, as long as you give appropriate credit to the original author(s) and the source, provide a link to the Creative Commons licence, and indicate if changes were made. The images or other third party material in this article are included in the article's Creative Commons licence, unless indicated otherwise in a credit line to the material. If material is not included in the article's Creative Commons licence and your intended use is not permitted by statutory regulation or exceeds the permitted use, you will need to obtain permission directly from the copyright holder. To view a copy of this licence, visit http://creativecommons.org/licenses/by/4.0/.

Publisher's note Springer Nature remains neutral with regard to jurisdictional claims in published maps and institutional affiliations.

The online version of the original article can be found at https://doi.org/ 10.1007/s10815-021-02224-y

Nejc Kozar

nejc@kozar.me; nejc.kozar@ukc-mb.si

1 Department of Reproductive Medicine and Gynaecological Endocrinology, Clinic for Gynaecology and Perinatology, University Medical Centre Maribor, Ljubljanska 5, 2000 Maribor, Slovenia

2 Faculty of Medicine, University of Maribor, Taborska ulica 8, 2000 Maribor, Slovenia 